\title{
PENGGUNAAN UMPATAN THELO, JIDOR, SIKEM, DAN SIKAK SEBAGAI WUJUD MARAH DAN EKSPRESI BUDAYA WARGA TEMANGGUNG
}

\author{
Use of the Thelo, Jidor, Sikem, and Sikak Requirements as a Treatment and Expression \\ of Temanggung Citizens Culture
}

Hamidulloh Ibda

Jurusan Tarbiyah STAINU Temanggung, Jawa Tengah

h.ibdaganteng@stainutmg.ac.id

Naskah Diterima Tanggal 15 Februari 2019-Direvisi Akhir Tanggal 5 November 2019—Disetujui Tanggal 10 Desember 2019 DOI : $10.26499 /$ rnh.v8i2.1293

\begin{abstract}
Abstrak
Penelitian ini bertujuan mendeskripsikan ujaran thelo, jidor, sikem, dan sikak sebagai umpatan khas Kabupaten Temanggung, Jawa Tengah. Kabupaten Temanggung dipilih sebagai lokasi pengambilan data dengan tujuan untuk mengungkap makna umpatan thelo, jidor, sikem, dan sikak dalam perilaku komunikasi warga. Jenis penelitian ini adalah kualitatif dengan menggunakan metode etnografi. Dari hasil penelitian, peneliti menemukan bentuk umpatan di Temanggung, yaitu berupa kata dan makian berbentuk frasa. Ada dua tujuan penggunaan ujaran thelo, jidor, sikem, dan sikak, yaitu; pertama, sebagai bentuk marah atau perlawanan atas kejahatan, anomali, atau kezaliman yang menimpa warga Temanggung, dan kedua, sebagai ekpresi budaya untuk mengungkapkan rasa senang, kagum, terkejut, dan heran. Ketika ada orang melakukan kejahatan pada salah satu warga, warga secara spontan mengucapkan thelo, jidor, sikem, atau sikak berdasarkan tingkat kejahatannya. Ujaran thelo, jidor, sikem, atau sikak tidak diucapkan untuk melakukan kejahatan, justru sebagai bentuk protes terhadap kejahatan. Ketika ada orang mencuri, warga biasa mengucap thelo, jidor, sikem, atau sikak atas kejadian tersebut.
\end{abstract}

Kata kunci: umpatan marah, ekspresi budaya, kearifan lokal Temanggung

\begin{abstract}
This study aims to describe the utterances of thelo, jidor, sikem, and sikak as typical curses of Temanggung Regency, Central Java. This study chose Temanggung Regency as the location for data collection aimed at revealing the meaning of thelo, jidor, sikem, and sikak in citizens' communication behavior. This type of research is qualitative using ethnographic methods.. From the results of the study, researchers found the form of swear in Temanggung, which is in the form of words and inscriptions in the form of phrases. There are two purposes for using the utterances of thelo, jidor, sikem, and sikak. First, as a form of anger or resistance to crime, anomalies, or tyranny that afflict the citizens of Temanggung. Second, as a cultural expression to express pleasure, admiration, surprise and wonder. When someone commits a crime on one of the residents, the citizen spontaneously pronounces thelo, jidor, sikem, or sikak based on his crime rate. The thelo, jidor, sikem, or sikak speeches are not spoken for committing a crime, instead as a form of protest against crime. When someone steals, people usually say thelo, jidor, sikem or sikak for the incident.
\end{abstract}

Keywords: angry views, cultural expressions, Temanggung local wisdom 
Penggunaan Umpatan...

How to Cite: Ibda, Hamidulloh. (2019). Penggunaan Umpatan Thelo, Jidor, Sikem, dan Sikak Sebagai Wujud Marah dan Ekspresi Budaya Warga Temanggung. Ranah: Jurnal Kajian Bahasa, 8 (2), 172-188. https://doi.org/10.26499/rnh.v8i2.1293

\section{PENDAHULUAN}

Setiap daerah memiliki local knowledge (pengetahuan lokal), local genius (jenius lokal), dan local wisdom (kearifan lokal) sendiri. Salah satunya berupa bahasa yang menjadi ciri khas masyarakat tertentu. Bahasa lokal tersebut pasti ragam bahasanya berbeda, unik, dan memiliki makna tersendiri karena lahir sesuai dengan budaya masyarakatnya. Keunikan bahasa yang berbeda tersebut, menunjukkan keragaman bahasa dan budaya di nusantara. Secara umum, pemaknaan bahasa lokal di suatu daerah yang termasuk kategori ragam bahasa muakan, makian, dan umpatan dimaknai sebagai bahasa kasar dan negatif. Namun sebaliknya, bahasa itu merupakan bagian dari ragam bahasa tertentu, lalu bagi masyarakat tersebut justru sebagai bentuk kemesraan serta ekspresi budaya mereka.

Bahasa berkaitan dengan ucapan rakyat (redensarten) termasuk gaya bahasa yang digunakan di setiap bidang kehidupan manusia, dapat secara personal atau kelompok di dalam masyarakat yang lebih luas. Ucapan rakyat dapat dipengaruhi kebiasaan, perilaku masyarakat tersebut dan menjadi cermin karakter nasional. Goethe, pengarang klasik asal Jerman, menulis pendapat bahwa seseorang harus benar-benar menyatu dengan tempatnya, maka jika sudah demikian ia benar-benar mendapat identitas yang mewakili bangsanya sendiri (Liwoso, 2012, hlm.19).

Di Jawa banyak sekali jenis budaya yang di dalamnya ada bahasa yang secara umum menjadi penanda identitas suatu daerah. Bahasa Jawa, Sunda, Madura, dan Betawi, tentu memiliki keunikan dan ragam tersendiri. Begitu juga dengan bahasa umpatan, makian, atau ekspresi marah terhadap orang atau sesuatu, tentu setiap daerah memiliki bentuk kata dan ragam bahasa tersendiri.

Ragam bahasa tersebut sering disebut umpatan, makian, pisuhan, nesunan, dan lainnya. Contoh yang sudah familiar adalah asu, asem, celeng, cukimai, dancuk, gendeng, gateli, gapleki, jancuk, kakeane, matane, perek, dan pekok. Umpatan dapat berupa kata, frasa, dan kalimat. Umpatan ini muncul beragam sesuai kondisi sosial, kultur, dan kearifan budaya di daerah. 
Sementara dari beberapa konteks, ada sepuluh macam. Pertama, umpatan berupa nama anggota tubuh, contohnya ndasmu, gundulmu, dhengkulmu, dan matamu. Kedua, umpatan berupa nama binatang, contohnya asu, kirik, jangkrik, tekek, dan sapi. Ketiga, umpatan berupa nama profesi bermakna negatif, contohnya bajingan, copet, lonthe, dan sontoloyo. Keempat, umpatan berupa nama bagian pohon, misalnya asem dan semprul. Kelima, nama peralatan makanan, seperti cangkire, dan ceret. Keenam, umpatan berupa nama anggota keluarga seperti mbahmu, dan mbahmu kiper. Ketujuh, umpatan berupa nama orang, contohnya basiyo, dan gombale mukiyo. Kedelapan, umpatan berupa kata yang tidak mempunyai referen, seperti ndlogok, bajinguk, dan bajiret. Kesembilan, umpatan yang berupa kondisi inteligensia seperti goblok, pekok, idiot, koplo, dan ngeces. Kesepuluh, umpatan yang berkaitan dengan kesehatan mental seperti edan, gendheng, lenyeng, kenthir, dan stres (Djatmika, 2016, hlm. 25).

Terdapat banyak bentuk kata-kata umpatan yang sering digunakan masyarakat. Ada yang menggunakan nama-nama hewan, anggota tubuh, atau kata sifat sebagai unsur pembentuknya. Contohnya adalah kata asu (anjing), bedhes (kera), matamu (matamu), lambemu (bibirmu), goblok (bodoh), dan fuck (bersetubuh). Dilihat dari segi ekspresi kebahasaan, umpatan merupakan suatu usaha penuturan untuk menyampaikan perasaan-perasaan dan pikiran-pikiran dalam bentuk satuan-satuan bahasa tertentu yang dianggap paling tepat dan paling mengena (Putra, 2013, hlm. 95).

Penggunaan umpatan itu tentu tidak sekadar persoalan emosi, ungkapan marah, melawan, atau protes terhadap penindasan yang menimpa pada manusia. Akan tetapi, umpatan itu muncul juga karena faktor budaya tertentu. Dalam konteks ini, ada beberapa emosi yang terungkap ketika manusia mengucapkan bahasa dengan ragam tertentu.

Ada enam macam emosi pada diri manusia, yaitu gembira, terkejut, sedih, marah, takut dan benci (Feldman, 1985, hlm. 114). Dalam perkembangannya, kata umpatan selain diucapkan untuk mengungkapkan emosi kemarahan, juga digunakan sebagai ekspresi takjub dan terkejut. Kata umpatan juga berfungsi sebagai bentuk sapaan, penanda kemesraan budaya, dan gurauan kepada orang yang mempunyai hubungan akrab. Untuk menunjukkan ekspresi marah, benci dan terkejut biasanya orang-orang menggunakan kata-kata umpatan karena kata-kata umpatan dapat digunakan untuk mengungkapkan salah satu dari emosi tersebut. 
Penggunaan kata-kata baik lisan maupun tulisan memiliki banyak ragam. Ragam bahasa merupakan variasi bahasa yang digunakan dalam situasi, keadaan atau untuk keperluan tertentu (Partana, 2002, hlm. 31). Dalam hal ini, ragam bahasa menjadi bagian dari kajian sosiolinguistik, karena menjadi perwujudan interaksi masyarakat bahasa yang pemakaiannya disesuaikan dengan fungsi, situasi dan perasaan sosial pemakaian bahasa itu sendiri.

Salah satu bentuk ragam itu adalah ragam sosial yang harus ditinjau dari perspektif yang komprehensif. Ragam sosial ini digunakan masyarakat untuk mengungkapkan, mengekpresikan, dan menginformasikan tujuan tertentu. Variasi bahasa yang digunakan oleh sekelompok orang dalam bidang sosial, pekerjaan, kelas, dan ragam tertentu disebut register.

Wardaugh dalam Purnanto (2002, hlm. 19) menjelaskan register sebagai pemakaian kosakata khusus yang berkaitan dengan kelompok-kelompok masyarakat atau jenis pekerjaan tertentu. Contohnya register petani, nelayan, guru, warga pedesaan, dan warga perkotaan. Register berkaitan dengan pemakaian bahasa atau fungsi bahasa. Variasi bahasa muncul karena adanya masyarakat pengguna bahasa yang heterogen. Register muncul pada bidang pekerjaan tertentu. Penggunaan variasi bahasa ini mempunyai karakteristik yang berbeda dengan bahasa yang digunakan oleh komunitas lain.

Di dalam dan luar negeri banyak penelitian yang mengkaji umpatan. Dalam riset di Iran ditemukan jenis umpatan atau sumpah yang lahir karena masalah agama. Dari jenis umpatan dalam penelitian ini menggunakan bahasa Persia modern. Jenis umpatan tersebut meliputi umpatan atas nama agama, saat kondisi suci, makanan dan minuman, bagian tubuh dan anggota keluarga masing-masing (Mahjub, dkk, 2013, hlm. 43).

Dalam penelitian di Malaysia ditemukan beberapa umpatan yang diucapkan pada kelompok perempuan tertentu. Beberapa umpatan itu berupa nama kotoran, sialan, pelacur (perek), bercinta, dan omong kosong (Paramasivam; Baudin, 2014, hlm. 14).

Sriyanto dan Fauzie (2017, hlm. 88) meneliti umpatan “jancuk” yang digunakan masyarakat desa (kampung) di Surabaya untuk mengungkapkan perasaan positif dan negatif kepada masyarakat lain. Dalam riset ini ditemukan bahwa kata "jancuk" menjadi positif ketika diungkapkan dalam interaksi pertemanan, persahabatan, dan 
ketika kondisi pergaulan sehari-hari. Kata “jancuk” menjadi buruk ketika digunakan untuk mengekspresikan rasa marah kepada orang lain.

Riset Setiawan (2016, hlm. viii) yang meneliti tentang umpatan kuli panggul bawang di Pasar Legi Surakarta menemukan bentuk umpatan berupa kata dasar dan turunan, frasa (nomina dan ajektiva), klausa (nomima dan ajektiva) yang berfungsi untuk mengekspresikan rasa menyesal, kesal, marah, menghina, heran, serta kecewa, dan penanda keakraban.

Dari riset-riset tersebut, keunikan dalam penelitian ini selain pada penuturnya juga terletak pada kata-katanya. Jika umpatan di luar Malaysia menggunakan bahasa asing, di Surabaya menggunakan jancuk atau dancuk, di Surakarta menggunakan kata dasar, turunan, frasa, dan klausa, di Temanggung memiliki kosakata umpatan thelo, jidor, sikem, dan sikak. Umpatan ini hanya digunakan dan diucapkan dalam kondisi dan di tempat tertentu sebagai ungkapan marah, ekspresi budaya, spontanitas, keakraban, dan sebagainya. Keunikan inilah yang mendorong peneliti untuk mengkaji lebih dalam.

Penggunaan bahasa Temanggung dapat disebut bahasa Jawa Temanggungan yang merupakan usaha pemertahanan bahasa ibu. Bahasa ini merupakan bahasa pertama, maka harus ada usaha pemertahanan sebagai bagian dari upaya menjaga kekayaan bahasa di negeri ini. Dalam hal ini, warga Temanggung, khususnya petani tembakau memiliki ragam bahasa umpatan yang menarik jika dibandingkan dengan daerah lain dengan ragam dan register tertentu. Umpatan ini lambat laun berkembang dan diucapkan warga Temanggung pada umumnya. Lahirnya umpatan khas Temanggung ini tidak lain karena hasil budaya masyarakatnya. Artinya, umpatan ini khas dan lahir dari pribumi, tidak impor atau serapan dari bahasa asing.

\section{LANDASAN TEORI}

Penelitian ini menggunakan pendekatan kajian sosiolinguistik sebagai dasar untuk mengalisis data yang didapatkan peneliti. Penelitian terhadap umpatan thelo, jidor, sikem, dan sikak termasuk kajian sosiolinguistik karena bahasa atau ujaran ini muncul hanya di Kabupaten Temanggung dan diungkapkan dalam situasi tertentu.

Bahasa merupakan konteks budaya, bahasa bukan sekadar alat untuk mengomunikasikan realitas. Bahasa merupakan alat untuk menyusun sebuah realitas. Bahasa yang berbeda akan mengonstruksi dan mengekspresikan realitas yang berbeda 
pula. Mempelajari bahasa menjadi langkah awal dalam mendeskripsikan suatu kebudayaan dengan batasan-batasannya sendiri (Spradley, 2006, hlm. 25-26). Salah satu ragam bahasa yang lahir dari budaya adalah umpatan.

Kamus Besar Bahasa Indonesia, menyebut umpatan berasal dari kata umpat yang mempunyai arti perkataan keji (kotor dan sebagainya) yang diucapkan karena marah (jengkel, kecewa, dan sebagainya); cercaan; makian; sesalan (Hasan, dkk, 2005, hlm. 1244). Mengumpat berasal dari kata dasar umpat yang artinya perkataan keji (kotor dan sebagainya), yang diucapkan karena marah (jengkel, kecewa dan sebagainya), cercaan, makian dan sesalan (Depdiknas, 2008, hlm. 1526). Umpatan atau biasa disebut pisuhan termasuk komunikasi verbal yang menjalankan fungsi emotif bahasa dan bertujuan untuk menyatakan perasaan (Setiawan, 2016, hlm. viii).

Mengumpat berarti mengeluarkan umpatan memburuk-burukkan orang mengeluarkan kata- kata keji (kotor) karena marah (jengkel, kecewa dan sebagainya). Mengumpat adalah memburuk-burukkan orang, memfitnah, mencerca, mencela keras, mengomel, memaki, mengutuk orang karena merasa diperlakukan kurang baik (Poerwadarminta, 2007, hlm. 1336).

Fungsi umpatan memang kompleks. Ketika seseorang berada pada kondisi marah, dia akan mengucapkan kata-kata umpatan tanpa disadari. Dengan mengucapkan katakata umpatan dia akan merasa puas karena emosinya diluapkan dengan umpatan. Kata umpatan juga menjadi kebanggaan kelompok tertentu, yaitu sebagai lambang identitas diri atau kelompok. Biasanya kata umpatan yang difungsikan untuk hal tersebut digunakan para remaja. Kata umpatan juga dapat digunakan sebagai jalan atau cara mengekspresikan agresi tanpa cara kekerasan (Putra, 2013, hlm. 95).

Kosakata umpatan tidak sekadar bermakna jorok, kotor, dan saru, tetapi mengandung makna lain dalam komunikasi antarpribadi di daerah tertentu. Secara umum, umpatan diucapkan untuk memarahi, merendahkan, mencela, mengekspresikan emosi, mengutuk, dan sebagainya. Akan tetapi dalam situasi tertentu, umpatan itu bermakna positif karena melahirkan sapaan, keakraban, persahabatan, dan kerinduan. Contohnya di Jawa Timur khususnya di Surabaya, kata umpatan jancuk, dancu, entuk, dan $c u k$, yang berarti bersetubuh, kemudian digunakan sapaan antarpribadi. "Piye, Cuk, kabarmu? " yang berarti bagaimana kabarmu? 
Di Semarang juga sama, kata gondes, dan ndes, yang merupakan akronoim "gondrong desa” menjadi alat sapaan seperti “ojo ngono to, Ndes" (jangan seperti itu). Kata $c u k$, dan ndes, secara umum berfungsi seperti bro, guys, mas, mbak, kang, dan lainnya yang bergungsi sebagai sapaan, keakraban, dan persahabatan.

Pengungkapan umpatan disesuaikan dengan kondisi tertentu. Dalam sosiolinguistik, variasi bahasa umpatan salah satunya disesuaikan dengan tempat dan situasi tertentu. Pemakaian umpatan thelo, jidor, sikem dan sikak dalam konteks ini tidak dipakai dalam kondisi formal, tetapi muncul di tempat dan situasi tertentu ketika warga Temanggung marah dengan seseorang atau dalam kondisi tertentu.

Tempat dalam hal ini dibatasi oleh air, yakni keadaan tempat berupa gunung dan hutan yang menghasilkan variasi bahasa yang kita sebut dialek. Dialek berasal dari bahasa Yunani dialektos yang pada mulanya dipergunakan dalam hubungannya dengan keadaan bahasa Yunani pada saat itu. Ilmu tentang dialek disebut dialektologi. Untuk melukiskan hubungan dalam dialek, ada yang disebut geografis dialek yang merupakan cabang dari dialektologi yang mempelajari hubungan dalam ragam bahasa dengan bertumpu pada satuan ruang dan tempat terwujudnya ragam-ragam tersebut. Dialek regional dapat terlihat pada kriterium struktural, kriterium saling mengerti, dan kriterium sosiokultural (Sunahrowi, 2007, hlm. 3).

Selain dialek, variasi bahasa yang dipengaruhi oleh tempat adalah bahasa daerah, kolokial dan vernakular. Bahasa daerah adalah bahasa yang dipakai oleh masyarakat yang tinggal di daerah tertentu, misalnya bahasa Temanggung.

Kolokial adalah bahasa sehari-hari yang digunakan pemakai bahasa yang tinggal di daerah tertentu, misalnya bahasa sehari-hari warga Temanggung. Kolokial disebut juga bahasa pasar, bahasa populer, atau bahasa percakapan. Vernakular adalah bahasa lisan yang berlaku di daerah tertentu.Variasi bahasa dilihat dari segi situasinya, terdiri atas bahasa dalam situasi resmi dan bahasa yang dipakai dalam situasi tidak resmi. Bahasa dalam situasi resmi, adalah bahasa yang dipakai dalam tulis-menulis ilmiah, seperti perundang-undangan dan dalam pertemuan resmi, seperti khotbah Jumat dan pertemuan kenegaraan. Bahasa dalam situasi resmi biasanya berupa bahasa standar, sedangkan bahasa dalam situasi tidak resmi biasanya ditandai keintiman antarpembicara dan menggunakan bahasa yang tidak standar (Sunahrowi, 2007, hlm. 7). 
Variasi bahasa muncul disebabkan kegiatan interaksi sosial yang dilakukan masyarakat atau kelompok yang sangat beragam dan para penuturnya tidak homogen. Ada dua pandangan dalam variasi bahasa ini. Pertama, variasi dilihat sebagai akibat adanya keragaman sosial penutur bahasa itu dan keragaman fungsi bahasa itu. Variasi bahasa itu terjadi sebagai akibat adanya keragaman sosial dan keragaman fungsi bahasa. Kedua, variasi bahasa itu sudah ada untuk memenuhi fungsinya sebagai alat interaksi dalam kegiatan masyarakat yang beraneka ragam. Dalam pandangan sosiolinguistik, bahasa tidak saja dipandang sebagai gejala individual, tetapi merupakan gejala sosial. Sebagai gejala sosial, bahasa dan pemakaiannya tidak hanya ditentukan oleh faktorfaktor linguistik, tetapi juga oleh faktor-faktor nonlinguistik (Kusmiyati, 2017, hlm. 46).

Dari penjelasan tersebut, dapat dikatakan bahwa umpatan merupakan ragam bahasa yang digunakan dalam kondisi tertentu. Mengumpat berarti mengeluarkan umpatan memburuk-burukkan orang, dan mengeluarkan kata- kata keji (kotor) karena marah (jengkel, kecewa dan sebagainya). Mengumpat adalah memburukburukkan orang, memfitnah, mencerca, mencela keras, mengomel, memaki, dan mengutuk orang karena merasa diperlakukan kurang baik. Penutur yang menggunakan umpatan kepada mitra tutur tidak selalu mengungkapkan kemarahan, tetapi juga terdapat makna lain, karena termasuk bagian dari budaya masyarakat tertentu.

\section{METODE PENELITIAN}

Metode yang digunakan dalam penelitian ini adalah etnografi. Etnografi menurut Spradley merupakan pekerjaan untuk menjelaskan sebuah budaya. Tujuannya untuk memahami cara hidup orang lain dari perspektif mereka sendiri. Metode etnografi berarti metode khusus untuk memahami budaya masyarakat dalam karakteristik dan bentuk tertentu. Etnografer atau peneliti etnografi dalam melakukan penelitian harus mengikuti kehidupan sehari-hari orang dalam periode lama, melihat apa yang terjadi, mendengar apa yang dikatakan, bertanya kepada mereka, dan pada kenyataannya mengumpulkan data apa saja yang ada (Koeswinarno, 2015, hlm. 259-261). Metode etnografi dalam penelitian ini dilakukan dengan analisis mendalam terhadap kebudayaan atau bahasa umpatan yang diteliti dengan sejarah kebudayaan suatu kelompok masyarakat Temanggung. 
Dalam hal ini etnografer terlibat langsung dalam kehidupan keseharian warga Temanggung sebagai bentuk pengamatan dan pengambilan data di lapangan. Sumber data penelitian berasal dari umpatan dalam bahasa Temanggung yang didapat langsung dari informan, khususnya petani tembakau. Data penelitian berupa kata-kata atau kalimat yang mengandung umpatan bahasa Temanggung. Hasil penelitian berupa ragam bentuk umpatan bahasa Temanggung yang sesuai dengan konteks penggunaannya dalam kehidupan sehari-hari ditinjau dari segi lahirnya, tempat dan situasi penggunaannya.

Metode yang peneliti gunakan dalam proses pengumpulan data adalah metode simak. Melalui metode ini peneliti menyimak secara langsung penggunaan kosakata umpatan di Temanggung. Metode ini memiliki seperangkat teknik yaitu teknik dasar dan teknik lanjutan. Teknik dasarnya adalah teknik sadap sedangkana teknik lanjutan yang digunakan dalam penelitian ini adalah teknik Simak Bebas Libat Cakap (SBLC). Teknik Simak Bebas Libat Cakap merupakan teknik yang dilakukan saat mengumpulkan data dengan menyimak pengguna bahasa tanpa ikut berpartisipasi dalam proses pembicaraan (Kesuma, 2007, hlm. 44).

Teknik tersebut digunakan peneliti karena data yang digunakan berasal dari kosakata umpatan yang diungkapkan warga Temanggung. Selanjutnya peneliti juga menggunakan teknik catat dalam pengumpulan data karena semua data yang diperoleh dicatat dan selanjutnya dianalisis sesuai dengan tema penelitian ini. Peneliti menyimak penggunaan umpatan dalam pembicaraan sehari-hari. Semua data yang sudah terkumpul dianalisis dengan menggunakan sebuah metode. Metode analisis data yang peneliti gunakan adalah metode padan.

Padan merupakan metode analisis bahasa yang alat penentunya berada di luar, terlepas, dan tidak menjadi bagian dari bahasa yang bersangkutan (Sudaryanto, 2015, hlm. 15). Metode padan yang sesuai adalah metode pragmatis karena peneliti menganalisis data terkait dengan konteks bahasa umpatan yang diucapkan warga Temanggung.

\section{PEMBAHASAN}

\section{Thelo, Jidor, Sikem, dan Sikak sebagai Umpatan Khas Temanggung}

Umpatan khas Temanggung thelo, jidor, sikem, dan sikak, dalam sejarahnya berawal dan lahir dari petani tembakau. Umpatan ini muncul sejak adanya tembakau 
khususnya yang dikembangkan petani di lereng Gunung Sindoro dan Gunung Sumbing. Awal kali penanaman tembakau di Sindoro dan berasal dari cerita tutur warga Temanggung yang menyebut nama Ki Ageng Makukuhan, anggota Dewan Santri, murid Sunan Kudus dan Sunan Kalijaga.

Tembakau pada mulanya dipercaya memberikan kehidupan dan sebagai obat. Tembakau ditanam Ki Ageng Makukuhan di lereng Sumbing. Ki Ageng Makukuhan adalah adik Raden Sutawijaya, yang merupakan Raja Mataram I, sementara Ki Ageng memilih menjadi petani yang mengembangkan tembakau dan beberapa tanaman lain di Sumbing dan sekitarnya (Moerti, 2016).

Perkembangan tembakau begitu pesat dan menjadi mata pencaharian dan kehidupan utama warga Temanggung. Akan tetapi, dinamika politik global memunculkan berbagai gerakan antitembakau, antirokok, dan diskriminasi terhadap petani tembakau. Hal itu melahirkan berbagai perlawanan kultural, dan ekspresi seni budaya kreatif, yang kemudian melahirkan ragam bahasa termasuk umpatan thelo, jidor, sikem, dan sikak.

Kemunculan diskriminasi, undang-undang, dan kebijakan yang memojokkan bahkan berpotensi mematikan petani tembakau melahirkan berbagai ragam ekspresi budaya. Beragam bentuk perlawanan masyarakat tembakau terhadap gerakan antitembakau dengan produk hukumnya pun bermunculan secara masif. Misalnya, aksi protes, demo, dan pembakaran tembakau, yang menunjukkan wujud kekecewaan mereka terhadap aturan yang akan mengikat, bahkan memarginalkan mereka sebagai petani sekaligus produsen tembakau (Purwantoro, 2015, hlm. 7).

Ungkapan kegelisahan, protes, kritik, dan kemarahan dimasukkan ke dalam alur cerita dan pada adegan dagelan, sebagai tradisi turun temurun yang masih eksis hingga saat ini dan menjadi ruang ekspresi rakyat kalangan bawah. Kesenian rakyat tradisional masyarakat pegunungan menjadi wadah komunikasi dalam mempererat kebersamaan warga. Masyarakat tidak hanya bekerja, berkeluarga, serta mencari sandang, pangan, dan papan, tetapi juga berkesenian untuk memenuhi kebutuhan batin, misalnya seni pertunjukan ketoprak yang tidak hanya sebatas pertunjukan atau hiburan semata. Keberadaan seni ketoprak menjadi media untuk menyalurkan suara-suara dan pikiran masyarakat petani tembakau. 
Ungkapan pikiran tersebut biasanya dituangkan dalam adegan dagelan sebagai kritik atas kekecewaan mereka secara tersamar. Walaupun kritik mereka tidak didengar oleh penguasa, yang terpenting bagi mereka adalah pikiran dan perasaannya dapat tersalurkan. Ungkapan kritik pun dilakukan dengan gaya bahasa mereka sendiri melalui dialog dan bahasa tubuh secara satir dan simbolik (Purwantoro, 2015, hlm. 9-10).

Aneka ragam umpatan di Temanggung pun bermunculan dalam rangka perlawanan dan ekspresi budaya. Di antaranya adalah thelo, jidor, sikem, dan sikak yang hanya diucapkan warga Temanggung ketika dalam kondisi tertentu. Warga Temanggung mengartikan thelo atau telo sebagai ungkapan “sialan”, yang berasal dari kata telo atau singkong. Dalam perspektif Jawa, telo atau singkong merupakan makanan paling rendah, karena dulu identik dengan gaplek atau semacam makanan zaman dahulu yang identik dengan kemiskinan.

Kemudian jidor atau jedor, yang artinya masih sama, yaitu "sialan”, "nggak penting”, “masa bodoh", "kurang ajar”, "nggak urusan”, dan sebagainya. Jidor diambil dari nama alat musik yang biasanya digunakan untuk kasidah, terbang, dan njanen atau berjanzen kesenian lokal di Temanggung. Sikem merupakan umpatan yang bermakna "sialan" sebagai bentuk penghalusan dari sikak yang bermakna "kurang ajar", "sialan", dan sebagainya. Sikak, bagi warga Temanggung diambil dari bulu kemaluan seorang perempuan.

Dari ragam umpatan ini, ada klasifikasi atau kelas kasar. Umpatan paling kasar adalah sikak, kemudian sikem, jidor, dan level paling halus adalah thelo. Sebagai bahasa umpatan, warga Temanggung memilih umpatan itu karena paling halus dan jarang ada di daerah lain. Meski demikian, di Temanggung sendiri ada umpatan yang umum seperti celes (sebagai wujud penghalusan dari celeng) dan asem (sebagai penghalusan dari asu). Akan tetapi, celes dan asu sangat jarang digunakan. Yang paling banyak adalah umpatan thelo, jidor, sikem, dan sikak.

\section{Makna Umpatan Thelo, Jidor, Sikem, dan Sikak sebagai Umpatan Khas Temanggung}

Umpatan khas Temanggung itu berupa kata dasar thelo, jidor, sikem, dan sikak, kemudian yang kedua berupa frasa, atau kalimat tidak lengkap yang menggunakan katakata itu ke dalam sebuah frasa untuk mengucapkan umpatan. Sebagai masyarakat yang terpengaruh dengan budaya berbahasa halus dari Surakarta dan Yogjakarta, warga 
Penggunaan Umpatan...

Temanggung memiliki tujuan tertentu dalam mengungkapkan umpatan khas thelo, jidor, sikem, dan sikak. Artinya, tidak semua penutur mengucapkannya kepada mitratutur secara sembarangan.

Umpatan digunakan sebagai penanda budaya tertentu. Kebanyakan secara terangterangan mereka menggunakan kata umpatan untuk melampiaskan emosi dan gejolak hati yang terpendam. Hal itu menunjukkan bahwa kata-kata itu muncul karena pendekatan afektif yang menimbulkan kekuatan ketika seseorang marah (Sudaryanto, 1993, hlm. 85).

Umpatan sebagai sebuah ragam dalam bahasa memiliki makna unik. Pasalnya bahasa merupakan wujud ekspresi atau lebih tepatnya a mirror of mind atau cermin pikiran manusia (Chomsky, 1975, hlm. 4). Pikiran itu diungkapkan dalam wujud katakata yang menjadi simbol budaya. Secara etnografi, sistem makna budaya disandikan ke dalam simbol-simbol, dan bahasa dalam hal ini merupakan sistem simbol utama yang menyandikan makna budaya dalam setiap masyarakat. Bahasa dapat digunakan untuk mengekpresikan budaya masyarakat setempat. Makna simbol apa pun, merupakan hubungan simbol dengan simbol lain dalam suatu budaya tertentu (Spradley, 2006, hlm. 139).

Dalam konteks tertentu, warga Temanggung mengucapkan umpatan thelo, jidor, sikem, dan sikak yang memiliki makna tersendiri. Jika dianalisis, umpatan-umpatan ini memiliki makna masing-masing.

\section{Makna Umpatan Thelo}

\section{Data 1}

Thelo tenan kuwe, janji ora ditepati.

Sialan benar kamu, berjanji tetapi tidak ditepati.

\section{Konteks Umpatan}

Seorang warga marah dengan temannya karena selalu ingkar janji.

\section{Data 2}

Thelo, piye kabare? Nyong suwe ra ketemu awakmu.

Sialan, bagaimana kabarnya? Aku lama tidak bertemu dirimu.

\section{Konteks Umpatan}

Seorang pemuda yang lama tidak bertemu temannya, yang menyapanya dengan umpatan sebagai penanda keakraban.

Umpatan thelo pada data 1 ini memiliki makna marah. Warga Temanggung ketika merasa marah, jengkel, atau mendapatkan perlakuan tidak normal atau kejahatan, mereka cenderung berkata-kata thelo seperti pada data 1. Jika dianalisis, umpatan thelo 
pada data 1 merupakan bentuk marah karena terjadi anomali (ketidakwajaran) dari masyarakat lain, tokoh publik, serta pengepul tembakau yang ditimpa, dilihat, atau dialami penutur umpatan. Hal itu sesuai dengan tujuan atau fungsi umpatan tersebut.

Data 2 memiliki makna sebagai penanda keakraban. Ketika mereka bertemu teman lama yang lama tidak menyapa, sebagai penanda keakraban mereka mengucapkan thelo. Baik pada data 1 maupun data 2, umpatan thelo ini bagi masyarakat didefinisikan sebagai umpatan yang paling halus daripada yang lain.

\section{Makna Ujaran Jidor}

\section{Data 3}

Jidor, grader kae ngedunke rego bako ora wajar.

Kurang ajar, grader (pengepul tembakau) itu menurunkan harga tembakau tidak wajar.

\section{Konteks Umpatan}

Petani marah kepada grader yang menurunkan harga tembakau seenaknya sendiri

\section{Data 4}

Jidor tenan, sak iki nyong luweh gandem karo awakmu.

Sialan beneran, sekarang aku lebih mantab dengan dirimu.

\section{Konteks Umpatan}

Seorang yang jatuh cinta dengan lawan jenis dan mengaku mantab menjalin hubungan serius.

Umpatan jidor pada data 3 memiliki makna marah ketika seorang grader menurunkan harga semaunya sendiri. Namun pada data 4, umpatan jidor diucapkan untuk mengekspresikan rasa takjub, heran kepada mitra tutur (orang lain). Pada data 3 dan data 4, umpatan jidor sudah mulai kasar pada level 2, baik diucapkan ketika marah maupun ketika ekspresi heran/takjub.

\section{Makna Ujaran Sikem}

\section{Data 5}

Sikem, anggota dewan sing gawene korupsi, besuk ora usah dicoblos maneh.

Sialan, anggota DPR yang pekerjaannya korupsi, besok tidak perlu dipilih lagi.

\section{Konteks Umpatan}

Warga marah, dan berpendapat kepada temannya ketika ada anggota DPR yang korupsi, dia tidak perlu dipilih lagi saat pemilu.

\section{Data 6}

Jan sikem, dek e luwih seneng lintingan daripada filter.

Sialan, dia lebih senang merokok lintingan daripada rokok filter.

\section{Konteks Umpatan}

Seseorang menceritakan temannya yang lebih suka merokok dengan lintingan daripada merokok filter. 
Penggunaan Umpatan...

Umpatan sikem pada data 5 memiliki makna marah karena melihat anomali (ketidaknormalan) terjadi pada anggota DPR karena korupsi. Mereka juga berpendapat bahwa anggota DPR yang seperti itu tidak perlu dipilih lagi. Sementara, pada data 6 umpatan sikem bermakna penanda keakraban dalam sebuah percakapan, yang mengungkapkan bahwa temannya lebih menyukai rokok dengan linting daripada filter. Umpatan sikem pada data 5 dan data 6 sudah termasuk kategori kasar level 3. Jarang orang yang mengucapkan umpatan ini ketika tidak benar-benar dalam kondisi marah keras.

\section{Makna Ujaran Sikak}

\section{Data 7}

Kepala dinas kok selingkuh wae, sikem tenan.

Kepala dinas kok selingkuh terus, sialan benar.

\section{Konteks Umpatan}

Seorang warga marah karena mengetahui seorang kepala dinas melakukan perselingkuhan.

\section{Data 8}

Sikak, mosok wong wadon ora tahu adus bendino, juk piye ambune?

Sialan, masak perempuan tidak pernah mandi setiap hari, terus bagaimana baunya?

\section{Konteks Umpatan}

Seorang laki-laki membicarakan perempuan yang tidak pernah mandi dan heran serta berasumsi bahwa baunya pasti tidak enak

Umpatan sikak pada data 7 bermakna marah karena seorang warga mengetahui kepala dinas yang ketahuan selingkuh dan mencemarkan nama baik Temanggung, sedangkan pada data 8, umpatan sikak bermakna ekspresi heran karena ada seorang perempuan yang jarang mandi. Pada data 7, umpatan sikak termasuk kategori paling kasar. Ketika tidak berada pada posisi marah betul dan tingkat tinggi, masyarakat Temanggung tidak mungkin mengucapkan umpatan sikak. Ketika marah dalam kondisi normal, mereka lebih memiliki thelo, jidor atau sikem.

Umpatan pada data 8 bermakna heran tingkat tinggi. Warga Temanggung tidak akan mengucapkan sikak untuk ekspresi takjub/heran ketika dalam kondisi biasa-biasa saja. Umpatan sikak ini muncul sebagai ekpresi heran pada kategori atau level tinggi.

Selain wujud marah, perlawanan dengan kata-kata, pada umumnya, umpatan thelo, jidor, sikem, dan sikak ini dipahami sebagai bentuk ekspresi budaya. Hal itu dapat dilihat ketika warga Temanggung mengumpat. Selain ekspresi marah, budaya yang di 
dalamnya ada bahasa menjadi pembuktikan bahwa mengucapkan umpatan thelo, jidor, sikem, dan sikak menjadi bagian dari ciri khas budaya Temanggung.

Tidak sekadar untuk mengekspresikan rasa marah, umpatan-umpatan di atas merupakan pengungkapan rasa senang, kagum, terkejut, dan heran dengan seseorang, kondisi, atau situasi tertentu. Penggunaan umpatan yang diucapkan dalam bentuk frasa tersebut menjadi wujud ekpresi budaya bagi warga Temanggung. Budaya yang dimaksud berupa ekspresi khas, yaitu bahasa umpatan ketika seseorang dalam kondisi tekanan lahir batin dan mengungkapkan umpatan sesuai ekpresinya.

Saat seorang mengalami tekanan lahir batin, biasanya orang tersebut akan mengungkapkannya melalui suatu tuturan atau ekspresi bahasa tertentu untuk terlepas dari tekanan tersebut. Ketika seseorang sedang marah, jengkel, senang, kagum, terkejut, sedih dan sebagainya, orang tersebut akan memilih bahasa yang dapat mengekspresikan perasaannya itu (Masykur, 2014, hlm. 4)

Ungkapan tersebut hanya ada di Temanggung dan menjadi kearifan lokal khas Temanggung. Kearifan lokal merupakan cara berpikir, bersikap, bertutur kata, dan bertingklah laku dari suatu daerah atau lokalitas yang sudah banyak dimengerti akan keluhuran budi dan kebaikan-kebaikannya, sehingga secara objektif perlu diteladani dan diikuti (Darmoko, 2010, hlm. 22). Salah satu bentuk kearifan lokal itu adalah cara bertutur kata warga Temanggung ketika ada kejahatan, anomali, atau penindasan yang menimpa seseorang, yang berupa umpatan thelo, jidor, sikem, dan sikak sebagai ekpresi budaya mereka.

\section{PENUTUP}

Dari temuan penelitian dan pembahasan yang telah diungkapkan bentuk makian warga Temanggung dibedakan menjadi dua, yaitu makian berbentuk kata atau makian berbentuk kata dasar, dan makian berbentuk frasa (makian yang lebih dari satu morfem). Dalam kata makian warga Temanggung terdapat dua jenis makna, yaitu sebagai wujud marah, serta perlawanan dan wujud ekspresi budaya yang menjadi bagian dari kearifan lokal di Temanggung.

\section{DAFTAR PUSTAKA}

Chomsky, N. (1975). The Logical Structure of Linguistic Theory. New York: Plenum Press.

Darmoko, D. (2010). Pedoman Pewayangan Berperspektif Perlindangan Saksi dan 
Korban (1st ed.). Jakarta: LPSK.

Depdiknas. (2008). Kamus Besar Bahasa Indonesia (1st ed.). Jakarta: Balai Pustaka. Djatmika. (2016). Mengenal Pragmatik Yux? (1st ed.). Yogyakarta: Pustaka Pelajar. Fauzie, S. S. A. (2017). Penggunaan Kata "Jancuk" Sebagai Ekspresi Budaya dalam Perilaku Komunikasi Arek di Kampung Kota Surabaya. Jurnal Psikologi Teori dan Terapan, 7(2), 88-102. Retrieved from https://journal.unesa.ac.id/index.php/iptt/article/view/1679

Feldman, R. S. (1985). Social Psychology (1st ed.). Amerika: Shaw and Wetherill, Inc.

Hasan, A, dkk. (2005). Kamus Besar Bahasa Indonesia. Jakarta: Departemen Pendidikan Nasional Balai Pustaka.

Kesuma, T. M. J. (2007). Pengantar Metode Penelitian Bahasa (1st ed.). Yogyakarta: Carasvatibooks.

Koeswinarno. (2015). Memahami Etnografi ala Spradley. Jurnal SMART (Studi Masyarakat, Religi, dan Tradisi), 1(2), 257-265. Retrieved from https://blasemarang.kemenag.go.id/journal/index.php/smart/article/download/256/ $\underline{176}$

Kusmiyati, A. J. W. W. (2017). "Bentuk dan Makna Kata Makian di Terminal Purabaya Surabaya dalam Kajian Sosiolinguistik". FONEMA, 4, 43-59.

Liwoso, Margaretha. (2012). "Pemahaman Terhadap Metafor Sebagai Sumber Kearifan Masyarakat." Ranah: Jurnal Kajian Bahasa, 1, 14-22. https://doi.org/https://doi.org/10.26499/rnh.v1i2.19.

Mahjub, M. A. Z. H. E. (2013). A Sociolinguistics Study of Conversational Swearing in Iran. International Journal of Linguistics, 5(3), 43-59. https://doi.org/https://doi.org/10.5296/ijl.v5i3.3899

Masykur, Purami Sarah Sita. (2014). Bentuk dan Fungsi Umpatan oleh Siswa SMA Negeri 2 Majene, Sulawesi Barat dalam Situasi Nonformal. Skriptorium, 2, 6375.

Moerti, W. (2016, August). Hikayat Tembakau sebagai Obat. Merdeka.Com. Retrieved from https://www.merdeka.com/khas/hikayat-tembakau-sebagai-obat.html.

Paramasivam, N. B. S. (2014). Swearing in English Among a Group of Female Malaysian Teenagers. International Journal of Contemporary Applied Sciences, $1(3), 14-25$.

Partana, S. P. (2002). Sosiolinguistik (1st ed.). Yogyakarta: Sabda.

Poerwadarminta, W. J. . (2007). Kamus Umum Bahasa Indonesia (III). Jakarta: Balai Pustaka.

Purnanto, D. (2002). Register Pialang Kendaraan Bermotor (1st ed.). Surakarta: Muhammadiyah University Press.

Purwantoro, A. (2015). Sikak-sikak Jidor: Resistenti Visual Petani Tembakau. Institut Seni Indonesia. Retrieved from http://digilib.isi.ac.id/987/1/BAB I.pdf

Putra, R. R. (2013). Bentuk dan Fungsi Kata Umpatan pada Komunikasi Informal di Kalangan Siswa SMA Negeri 3 Surabaya: Kajian Sosiolinguistik. Skriptorium, 1, 93-105. Retrieved from http://journal.unair.ac.id/SKRIP@bentuk-dan-fungsikata-umpatan-article-6725-media-45-category-8.html

Setiawan, N. (2016). Bahasa Umpatan Kuli Panggul Bawang di Pasar Legi Sukakarta (Kajian Pragmatik). Semarang: Universitas Negeri Semarang.

Spradley, J. P. (2006). Metode Etnografi (1st ed.). Yogyakarta: Tiara Wacana.

Sudaryanto. (1993). Metode dan Aneka Teknik Analisis Bahasa: Pengantar Penelitian Wahana Kebudayaan Secara Linguistik. Yogyakarta: Muhammadiyah University 
Press.

Sudaryanto. (2015). Metode dan Aneka Teknik Analisis Bahasa: Pengantar Penelitian Wahana Kebudayaan secara Linguistis. Yogyakarta: Duta Wacana University Press.

Sumadyo, B. (2013). Sekilas Tentang Bentuk Umpatan dalam Bahasa Indonesia. In 2nd International Seminar on Quality and Affordable Education (ISQAE 2013) (pp. 197-201). Jakarta: Faculty of Education Universiti Teknologi Malaysia. Retrieved from https://anzdoc.com/sekilas-tentang-bentuk-umpatan-dalam-bahasaindonesia.html

Sunahrowi. (2007). Variasi dan Register Bahasa dalam Pengajaran Sosiolinguistik. INSANIA: Jurnal Pemikiran Alternatif Pendidikan, 12, 81-92. Retrieved from http://ejournal.iainpurwokerto.ac.id/index.php/insania/article/view/233/203 